\title{
Cloning, expression, and purification of insect (Sitophilus oryzae) alpha-amylase, able to digest granular starch, in Yarrowia lipolytica host
}

\author{
Ewelina Celińska • Wojciech Białas • \\ Monika Borkowska $\cdot$ Włodzimierz Grajek
}

Received: 10 October 2014 / Revised: 4 December 2014 / Accepted: 9 December 2014 / Published online: 31 December 2014

(C) The Author(s) 2014. This article is published with open access at Springerlink.com

\begin{abstract}
Raw-starch-digesting enzymes (RSDE) are of major importance for industrial applications, as their usage greatly simplifies the starch processing pipeline. To date, only microbial RSDE have gained considerable attention, since only microbial production of enzymes meets industrial demands. In this study, $\alpha$-amylase from rice weevil (Sitophilus oryzae), the major rice pest, was cloned and expressed in Yarrowia lipolytica Polg strain. The enzyme was secreted into the culture medium, and the peak activity ( $81 \mathrm{AU} / \mathrm{L})$ was reached after only $29 \mathrm{~h}$ of culturing in 5-L bioreactors. Through simple purification procedure of ammonium sulfate precipitation and affinity chromatography, it was possible to purify the enzyme to apparent homogeneity ( 25 -fold purification factor, at $5 \%$ yield). The optimal conditions for the $\alpha$ amylase activity were $\mathrm{pH} 5.0$ and a temperature of $40^{\circ} \mathrm{C}$. The $\alpha$-amylase studied here did not show any obligate requirement for $\mathrm{Ca}^{2+}$ ions. The recombinant $\alpha$-amylase appeared to efficiently digest granular starch from pea, amaranth, waxy corn, and waxy rice.
\end{abstract}

Keywords Amylase · Granular starch · Rice weevil · Yarrowia lipolytica $\cdot$ Recombinant protein expression

\section{Introduction}

The search for novel enzymes with potential applications in industrial processes is receiving constantly increasing interest from the scientific and industrial community. $\alpha$-Amylases (EC 3.2.1.1, 1,4- $\alpha$-D-glucan-glucanohydrolases) are one of

E. Celińska $(\bowtie) \cdot$ W. Białas $\cdot$ M. Borkowska $\cdot$ W. Grajek Department of Biotechnology and Food Microbiology, Poznań University of Life Sciences, ul. Wojska Polskiego 48, 60-627 Poznań, Poland

e-mail: celinska@up.poznan.pl the most important industrially relevant enzymes, with a number of applications, i.e., baking, brewing, and textile and paper industry (Gupta et al. 2003; Pandey et al. 2000; van der Maarel et al. 2002). One of the most desired traits of $\alpha$ amylases is their ability to decompose raw, nonpretreated starch granules (Sun et al. 2010). Utilization of raw-starchdigesting enzymes (RSDE) allows elimination of the most energy-consuming and cost-inefficient step of starch slurry processing - gelatinization. Significant effort has been devoted to isolate raw-starch-digesting (RSD) amylases from various sources. RSD amylases are uniformly distributed among plant, animal, and microorganism species. However, only microbial RSD amylases have gained much attention, since production of enzymes in microorganisms generally meets industrial demands, like cost-/time-effectiveness, high productivity, ease of the process of modification, and optimization. Nevertheless, powerful genetic engineering methods surpass the limitations of the other sources of the enzymes and allow the production of any enzymatic activity in the preferred microbial host. Heterologous expression offers the possibility of production of potentially useful enzymes at high quantities, preferably secreted into the culture medium, which greatly facilitates their purification. Moreover, it has been reported that heterologous expression may change the properties of an enzyme, e.g., improve its thermal stability (Yuzbashev et al. 2012). RSDE have been most frequently cloned and expressed in either Escherichia coli or Saccharomyces cerevisiae hosts, and mostly genes from microbial origins have been investigated: Aspergillus awamori (Matsubara et al. 2004), various Bacillus species (Demirkan et al. 2005), Saccharomycopsis fibuligera (Hostinová et al. 2010), Cryptococcus (Iefuji et al. 1996), Cytophaga sp. (Jeang et al. 2002), Rhizopus oryzae ( $\mathrm{Li}$ et al. 2011), and Thermobifida fusca (Yang and Liu 2007). The latter gene was also expressed in other hosts, namely Pichia pastoris (Yang et al. 2010a) and 
Yarrowia lipolytica (Yang et al. 2010b), showing superior performance of the latter host.

In this study, we cloned $\alpha$-amylase (Amyl) gene from Sitophilus oryzae and expressed it in a nonconventional yeast species, Y. lipolytica. S. oryzae is primarily known as a major pest of stored rice, contributing to limitation of food availability for a large number of people. We assumed that high expansiveness of $S$. oryzae in cereal crops may be to some extent attributed to highly active digestive enzymes, especially amylases, synthesized by this insect. $Y$. lipolytica is a recognized system for heterologous protein expression (Barth and Gaillardin 1996; Madzak et al. 2004). Direct comparison of different expression platforms-Y. lipolytica, S. cerevisiae, P. pastoris, Arxula adeninivorans, Hansenula polymorpha, Kluyveromyces lactis, and Schizosaccharomyces pombe (Gellissen et al. 2005; Müller et al. 1998) - demonstrated that Y. lipolytica is characterized by several advantageous traits for heterologous protein expression over the other expression systems. Several detailed review papers regarding the applied strategies used vectors, and heterologous proteins expressed in Y. lipolytica are available in the literature (e.g., Madzak et al. 2004; Madzak and Beckerich 2013).

Not many studies on pure insect amylases can be found in the literature (e.g., Grossi de Sa and Chrispeels 1997; Titarenko and Chrispeels 2000). Usually studies are carried out in vivo or with a mixture of isolated isozymes. Isolation of relatively homogenous enzymatic preparation from small animals comprises laborious, multistep procedures, which does not meet the requirements for industrial production. Moreover, to isolate a sufficient amount of any enzyme, a number of individuals have to be used for a single isolation procedure, which may contribute to the variability of the material. Expression of enzymes in microbial hosts offers the possibility to eliminate the risk of the biological material variability within the population of differing, diploid individuals, sometimes at different life cycle stages.

This report comprises cloning and expression of S. oryzae $\alpha$-amylase in $Y$. lipolytica cells, production of this enzyme in 5-L bioreactors, purification through affinity chromatography, and determination of digestibility of various starch species, including raw, granular starch, by this enzyme.

\section{Materials and methods}

Strains, media composition, and small-scale culture conditions

Y. lipolytica Po1g strain was used as an expression host for the recombinant $A m y 1$ gene. It was routinely maintained on YPD medium $(\mathrm{g} / \mathrm{L})$ : yeast extract, 10 ; bactopeptone, 20 ; and glucose, 20 (agar, 20). Before any experiments, its $\mathrm{leu}^{-}$ phenotype was verified on YNB medium $(\mathrm{g} / \mathrm{L})$ : glucose, 20; yeast nitrogen base w/o amino acids, 6.7; and agar, 15. E. coli JM109 strain was used for the propagation of vectors. $E$. coli JM109 and all the derivatives were cultured in Luria-Bertani (LB) medium $(\mathrm{g} / \mathrm{L})$ : yeast extract, 5 ; bactopeptone, $10 ; \mathrm{NaCl}$, 10 ; and agar, 15 , supplemented with ampicillin $(100 \mathrm{mg} / \mathrm{L})$, when required. Flask cultivations were carried out in a rotary shaker, at $250 \mathrm{rpm}, 30$ or $37^{\circ} \mathrm{C}$ for Y. lipolytica and E. coli, respectively. All the strains used in this study are listed in Table 1.

DNA manipulation and vector construction

Standard molecular biology techniques were used throughout this study (Sambrook and Russell 2001). The sequence of the Amyl gene from S. oryzae (gb|HQ158012.1) was codonoptimized for expression in Y. lipolytica (gb|KP027641) at GenScript Facility (GenScript Inc., Piscataway, USA). Vectors and oligonucleotides used in this study are summarized in Table 1. Restriction enzymes, shrimp-alkaline phosphatase, and DNA molecular markers for electrophoresis were all purchased from Thermo Fisher Scientific Inc. (Waltham, MA, USA). DNA T4 ligase was obtained from New England Biolabs (UK). DNA Taq polymerase was purchased from Qiagen (Germany). PCR reactions were set up in a Veriti ${ }^{\circledR}$ Thermal Cycler (Applied Biosystems), using AMY_SfiI_F and AMY_KpnI_R primers $(0.5 \mu \mathrm{M}$ each $)$ and approx. $50 \mathrm{ng}$ of DNA template, in a final volume of $25 \mu \mathrm{L}$, using the following temperature profiles: $94{ }^{\circ} \mathrm{C}$ for $5 \mathrm{~min} ;\left(94^{\circ} \mathrm{C}\right.$ for $30 \mathrm{~s}$, $56{ }^{\circ} \mathrm{C}$ for $30 \mathrm{~s}, 72{ }^{\circ} \mathrm{C}$ for $\left.90 \mathrm{~s}\right) 25 \times ; 72{ }^{\circ} \mathrm{C}$ for $3 \mathrm{~min}$. All the reactions were set up according to the protocols recommended by the suppliers. The following steps were carried out with the use of an appropriate kit from A\&A Biotechnology (Gdynia, Poland): genomic DNA isolation from yeast (Genomic Mini AX yeast kit), plasmid DNA isolation (Plasmid Mini kit), and DNA fragment purification from agarose gel (Gel Out kit). Prior to transformation, the Amyl gene sequence was verified through sequencing (Genomed sequencing facility, Poland).

Transformation and selection of positive clones

E. coli JM109 competent cell preparation and heat-shock transformation were carried out according to standard protocols (Sambrook and Russell 2001). Positive clones were selected on $\mathrm{LB}+$ ampicillin agar plates and screened through plasmid mini-preparation and endonuclease digestion. Preparation of Y. lipolytica Po1g competent cells and transformation with the expression cassette were completed according to the protocol supplied by the manufacturer of the YLEX Expression kit (Yeastern Biotech Co., Ltd., Taiwan). Positive clones were selected on YNB plates. Phenotype verification was carried out on YPS medium $(\mathrm{g} / \mathrm{L})$ : yeast extract, 10; bactopeptone, 20; 
Table 1 Strains, vectors, and oligonucleotides used in this study

\begin{tabular}{|c|c|c|c|}
\hline Name & Characteristics & Use & Supplier/reference \\
\hline \multicolumn{4}{|l|}{ Strains } \\
\hline Yarrowia lipolytica Po1g & $\begin{array}{l}\text { Genotype: MatA, leu2-270, ura3-302::URA3, xpr2- } \\
\text { 332, axp-2; phenotype: Leu }, \triangle A E P, \triangle A X P, \text { Suc }+ \\
\text { pBR platform }\end{array}$ & $\begin{array}{l}\text { Parental strain-host for } \\
\text { expression of recombinant } \\
\text { Amyl gene }\end{array}$ & $\begin{array}{l}\text { Yeastern Biotech Co., Ltd., } \\
\text { Taiwan }\end{array}$ \\
\hline Yarrowia lipolytica 1.18 & $\begin{array}{l}\text { Genotype: MatA, leu2-270, ura3-302::URA3, xpr2- } \\
\text { 332, axp-2; phenotype: } L e u+, \triangle A E P, \triangle A X P, S u c+\text {; } \\
4 \text { copies of pYLSC-AMY }\end{array}$ & $\begin{array}{l}\text { Host for expression of } \\
\text { recombinant Amyl gene }\end{array}$ & This study \\
\hline Escherichia coli JM109 & $\begin{array}{l}F^{\prime}(\text { traD } 36, \text { proAB }+, \text { laclq }, \Delta(l a c Z) M 15), \text { end A1, } \\
\quad \text { recA1, hsdR17(rk-,mk+), mcrA, supE44, } \lambda- \\
\quad \text { gyrA96, relA1, } \Delta \text { (lacproAB), thi-1 }\end{array}$ & $\begin{array}{l}\text { Host for routine cloning, vector } \\
\text { propagation, assembly of a } \\
\text { complete vector }\end{array}$ & Sigma-Aldrich \\
\hline \multicolumn{4}{|c|}{ 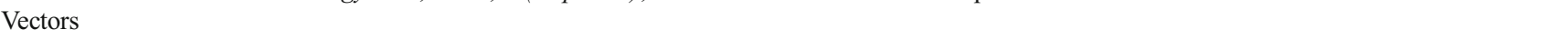 } \\
\hline pGEM-T-Easy & $\begin{array}{l}\text { https://pl.promega.com/resources/protocols/technical- } \\
\text { manuals/0/pgem-t-and-pgem-t-easy-vector- } \\
\text { systems-protocol/ }\end{array}$ & $\begin{array}{l}\text { Subcloning of the Amyl gene, } \\
\text { sequencing }\end{array}$ & Promega Co., USA \\
\hline pYLSC & $\begin{array}{l}\text { pBR322 backbone, hybrid promoter (hp4d), XPR2 } \\
\text { preregion, leucine gene (LEU2)_-selection marker; } \\
\text { AMY gene was cloned in SfiI/KpnI sites } \\
\text { http://www.yeastern.com/Products.php?pid=273 }\end{array}$ & $\begin{array}{l}\text { Expression vector used for } \\
\text { cloning and transformation of } \\
\text { Y. lipolytica Polg strain }\end{array}$ & $\begin{array}{l}\text { Yeastern Biotech Co., Ltd., } \\
\text { Taiwan }\end{array}$ \\
\hline \multicolumn{4}{|l|}{ Oligonucleotides } \\
\hline AMY_SfiI_F & AAGGCCGTTCTGGCC ATGAAGGTGCTCGCC & & This study \\
\hline AMY_KpnI_R & AAGGTACC CTAGTGGTGGTGGTGGTGGTGC & & \\
\hline $\begin{array}{l}\mathrm{r}-\mathrm{t} \text { _actin_F } \\
\mathrm{r}-\mathrm{t} \text { actin_R }\end{array}$ & $\begin{array}{l}\text { CGAGCGAATGCACAAGGA } \\
\text { GAGCGGTGATCTTGACCTTGA }\end{array}$ & $\begin{array}{l}\text { Real-time analysis - copy } \\
\text { number determination }\end{array}$ & Celińska and Grajek (2013) \\
\hline $\begin{array}{l}\text { r-t_AMY_F } \\
\text { r-t_AMY_R }\end{array}$ & $\begin{array}{l}\text { GTAACAACGTGGGAATCCGAAT } \\
\text { CCCTGGCCGTTCGAAGTAG }\end{array}$ & & This study \\
\hline
\end{tabular}

glucose, 20; agar, 20; and soluble starch, 10; after 24-h growth, the biomass was scraped and the $5 \%$ iodine solution $\left(\mathrm{I}_{2}\right.$ in $\left.\mathrm{KI}\right)$ was poured onto the plate to visualize translucent zones.

\section{Estimation of the recombinant gene copy number}

The number of the recombinant Amyl gene copies integrated with the host genome was estimated through real-time quantitative PCR analysis. The reaction was carried out using RealTime 2xPCR Master Mix SYBR kit A (A\&A Biotechnology, Gdynia, Poland). The reactions were set up according to the manufacturer's protocol in Applied Biosystems 7500 device. Real-time PCR primers targeting the Amyl gene (r-t_AMY_F and $r$ - $t$ _AMY_R ) and the actin-coding gene ( $r$-t_actin_F and $r$ $t$-actin- $R$ ), used as an endogenous control, were designed with Primer Expert Software (Applied Biosystems). The following temperature profiles were applied: $94{ }^{\circ} \mathrm{C} 5 \mathrm{~min} ;\left(94{ }^{\circ} \mathrm{C} 30 \mathrm{~s}\right.$, annealing temperature according to Primer Expert $15 \mathrm{~s}, 72^{\circ} \mathrm{C}$ $45 \mathrm{~s}) 40 \times$; $72{ }^{\circ} \mathrm{C} 5 \mathrm{~min}$; melt curve: $94{ }^{\circ} \mathrm{C} 15 \mathrm{~s}, 60{ }^{\circ} \mathrm{C} 60 \mathrm{~s}$, $95^{\circ} \mathrm{C} 30 \mathrm{~s}$, and $60^{\circ} \mathrm{C} 15 \mathrm{~s}$. Fluorescence from SYBR ${ }^{\circledR}$ Green was measured at the end of the elongation step. Samples were analyzed in triplicate. Data analysis was carried out according to the standard $\Delta \Delta \mathrm{C}_{\mathrm{T}}$ method (Livak and Schmittgen 2001).
Amylase activity assay

The amylase activity was determined by measuring the amount of reducing sugars released after incubation with starch. One milliliter of liquefied starch solution $(1 \% ; w / v)$ in acetate buffer (100 mM, pH 5.0) was used as the substrate. The reaction was initiated at the enzyme preparation addition $(0.4 \mathrm{~mL})$ and was continued for $30 \mathrm{~min}$ at $40{ }^{\circ} \mathrm{C}$. The concentration of reducing sugars was determined according to the Nelson-Somogyi method (Nelson 1944) versus a standard curve prepared with glucose. The concentration of background sugars contained within the enzymatic preparation was assessed and taken into account in the calculations. All the measurements were done in three technical replicates. One activity unit was defined as the amount of an enzyme that released reducing sugar ends equivalent to $1 \mu \mathrm{mol}$ of glucose per 1 min under the specified assay conditions.

For assessing the optimal assay temperature and $\mathrm{pH}$, the assay conditions were modified by incubating the reaction mixture at 25,30 , and $40{ }^{\circ} \mathrm{C}$ and dissolving starch in either

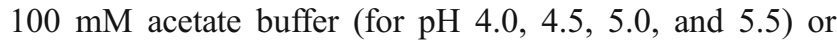
$100 \mathrm{mM}$ phosphate buffer (for $\mathrm{pH} 6.0$ and 6.5). $\mathrm{Ca}^{2+}$ dependence of the $\alpha$-amylase was verified by comparison of the enzyme activity toward the substrate with and without provision of $\mathrm{CaCl}_{2}$ at $2 \mathrm{mM}$ in the acetate buffer, pH 5.0. 
Amylase activity was determined in the culture medium and inside the yeast cells immediately after the collection of the samples. For the extracellular amylase activity, after separation of the biomass through centrifugation $\left(4234 \times g, 4^{\circ} \mathrm{C}\right.$, $10 \mathrm{~min}$ ), raw medium was added into the reaction mixture, without any preprocessing. The protein concentration was determined by the method described by Bradford (1976), using bovine serum albumin (BSA) as a standard.

\section{Preparation of protein extracts}

Protein extracts were prepared by resuspending the cellular pellets in breaking buffer $(0.1 \mathrm{M}$ sodium phosphate buffer, $5 \mu \mathrm{M}$ DTT, $1 \mathrm{mM}$ PMSF, $5 \%$ glycerol) with glass beads (Sigma-Aldrich Co., USA) and disruption of the cells by repeated cycles $(5 \times)$ of mixing at 30 strokes/s for $1 \mathrm{~min}$ in a Mixer Mill MM400 (Retsch) and incubation on ice for $1 \mathrm{~min}$. The cellular debris were then separated by centrifugation $(24$, $652 \times g, 4{ }^{\circ} \mathrm{C}, 10 \mathrm{~min}$ ).

Testing various starch types for digestibility by the new amylase

Digestibility of 11 starch species, of various botanical origin, was tested. The following starch types were analyzed: soluble potato, potato Z1, potato Z2S, waxy potato, waxy rice, waxy corn, corn, tapioca, pea, amaranth, and wheat. The starches were suspended in acetate buffer $(100 \mathrm{mM}, \mathrm{pH} 5.0)$ and either liquefied through autoclaving or provided into the reaction mixture as a granular substrate. For the liquefied substrates, the reaction lasted $30 \mathrm{~min}$, and $0.368 \mathrm{mAU}$ was added per reaction, while for the native, granular substrates, the reaction was continued up to $1 \mathrm{~h}$, and $38.6 \mathrm{mAU}$ was added into the reaction mixture. Digestion was followed by the NelsonSomogyi protocol for determination of reducing sugars.

\section{Bioreactor cultivations}

Bioreactor cultivations were carried out in BIOSTAT $^{\circledR}$ A plus (Sartorius) stirred tank bioreactors, with a total volume of $5 \mathrm{~L}$ and culture medium volume of $2 \mathrm{~L}$. The culture medium (YPG $(\mathrm{g} / \mathrm{L})$ : yeast extract, 10; bactopeptone, 20; glycerol, $100)$ was inoculated at $10 \%(v / v)$ with 22-h-old YPG culture. $\mathrm{pH}$ was adjusted to 5.5 by automatic addition of alkali $(20 \%$ $\mathrm{NaOH}$ ); no acid was fed into the bioreactor. The temperature was maintained at $30{ }^{\circ} \mathrm{C}$ throughout the culture. Stirring and aeration were automatically adjusted to maintain oxygen saturation of the culture at $30 \%$. Foam formation was minimized by automatic addition of Antifoam 204 (Sigma-Aldrich). Culture parameters were automatically monitored with BioPAT ${ }^{\circledR}$ MFCS SCADA. Dry cellular weight (DCW) was determined through a gravimetric method.
Enzyme purification through affinity chromatography

Extracellular proteins were precipitated with ammonium sulfate (to the final saturation of $80 \%$, at $4{ }^{\circ} \mathrm{C}$ ) for several hours. After centrifugation $\left(4234 \times \mathrm{g}, 4^{\circ} \mathrm{C}, 45 \mathrm{~min}\right)$, the proteins were resuspended in binding buffer (phosphate buffer, $20 \mathrm{mM}$, $\mathrm{pH} 7.4 ; \mathrm{NaCl}, 0.5 \mathrm{M}$; imidazole, $20 \mathrm{mM}$ ), filtered through a $0.45-\mu \mathrm{m}$ syringe filter (Millex, Millipore), and loaded onto the ÄKTA FPLC system (ÄKTA Pharmacia GE FPLC) equipped with a HisTrap HP column (5 mL, GE Healthcare), with $\mathrm{Ni}^{2+}$ ions immobilized on sepharose. The purification procedure was carried out under increasing gradient of elution buffer (phosphate buffer, $20 \mathrm{mM}$, pH 7.4; $\mathrm{NaCl}, 0.5 \mathrm{M}$; imidazole, $0.5 \mathrm{M}$ ) at the flow rate of $5 \mathrm{~mL} / \mathrm{min}$. Fractions were immediately analyzed for the amylase activity and subjected to sodium dodecyl sulfate-polyacrylamide gel electrophoresis (SDSPAGE), to identify the enzyme-enriched fraction and assess its purity.

Analytical procedures

\section{Electrophoresis techniques}

DNA fragments were resolved in $1 \%$ agarose gels in TBE buffer and stained with ethidium bromide. SDS-PAGE was carried out according to the standard method of Laemmli (1970); the proteins were resolved in $15 \%$ denaturating polyacrylamide gel. For zymography, the protein extracts from the pellets, the ammonium sulfate $(80 \%)$ concentrated proteins from the medium, or ÄKTA-purified $\alpha$-amylase was resolved in native $10 \%$ PAA gel, supplemented with $1 \%$ of liquefied soluble starch, and added prior to polymerization. After electrophoresis, the gels were incubated overnight in acetate buffer (100 mM, pH 5.0) with $2 \mathrm{mM} \mathrm{CaCl}_{2}$ and $10 \mathrm{mM} \mathrm{NaCl}$. The gels were revealed by incubation with $5 \%$ iodine solution.

\section{Scanning electron microscopy}

Prior to SEM analysis, the samples of digested and nondigested starch granules were subjected to repeated washing with $20 \mathrm{mM} \mathrm{NaOH}$ and $\mathrm{ddH}_{2} \mathrm{O}$, as previously described (Białas et al. 2013), and subsequently lyophilized. Lyophilization was carried out in vials in Christ Beta lyophilizator (Christ, Germany), applying the following parameters: initial freezing $-35{ }^{\circ} \mathrm{C}$; drying: condenser $-35{ }^{\circ} \mathrm{C}$, shelf $15{ }^{\circ} \mathrm{C}$, pressure $0.22 \mathrm{mbar}$, time $40 \mathrm{~h}$; and final drying: shelf $20^{\circ} \mathrm{C}$, pressure $0.18 \mathrm{mbar}$, time $8 \mathrm{~h}$. Samples were stored in a desiccator until analysis. The samples were placed on specimen stubs covered with double-sided adhesive tape and sprayed with gold particles (99.9 \%) in sputter coater BalTec SCD 050 (Balzers, Liechtenstein). The granules were 
observed and photographed using a scanning electron microscope (Zeiss EVO 40, Carl Zeiss AG, Oberkochen, Germany).

\section{Results}

Cloning and sequence analysis

The cDNA sequence encoding the $\alpha$-amylase (Amyl) gene from $S$. oryzae (gb|HQ158012.1) consists of $1458 \mathrm{bp}$ encoding 486 amino acid residues. This sequence was codon-optimized for cloning and expression in Y. lipolytica (gb|KP027641), to avoid codon usage incompatibility, which we have encountered in our previous study (Celińska and Grajek 2013). Codon-optimized sequence was $100 \%$ identical in primary amino acid structure with the original sequence from $S$. oryzae. Additionally, the Amyl sequence was tagged with a $6 \mathrm{xHis}$-tag, at the $\mathrm{C}$-terminus, to enable easier purification in an IMAC system. The calculated molecular weight of the protein was $53.9 \mathrm{kDa}$ (which was also confirmed by SDSPAGE in this study), and the theoretical isoelectric point, $\mathrm{p}$, was 4.92 (ExPASy, ProtParam, http://web.expasy.org/ protparam/). The sequence was also found to possess a 17amino-acid signal peptide at the N-terminus (PrediSi, http:// www.predisi.de/predisi/). The signal peptide appeared to be operable in Y. lipolytica, when the Amyl gene was cloned in pYLEX vector, not equipped with $Y$. lipolytica secretion signal (data not shown). Functionality of signal peptides from phylogenetically distant organisms in $Y$. lipolytica has been also reported for other proteins (Park et al. 1997; Yuzbashev et al. 2012). The amino acid sequence of the AMY protein was $70 \%$ similar to $\alpha$-amylase from Anthonomus grandis (gb|AAN77138.1|) and an unknown protein from Dendroctonus ponderosae (gb|AEE61654.1) and $68 \%$ similar to amylase A and amylase B protein sequence from Ips typographus (gb|ADQ54210.1 and $\mathrm{gb} \mid \mathrm{ADQ}$ 54211.1). The structure of the AMY protein, regarding the organization of the domains, was typical for the other amylases, with an "AmyAc_bac_euk_AmyA" domain (alpha-amylase catalytic domain found in bacterial and eukaryotic alpha-amylases) and a "C-terminal-all-beta" domain. Importantly, the $\mathrm{C}$-terminal binding domain is considered to be responsible for adsorption of the enzyme on the surface of starch granules (Jespersen et al. 1991). The occurrence of this domain is associated with the ability to digest raw starch granules, as it was reported for fungal glucoamylases from Rhizopus and Aspergillus or bacterial $\beta$-amylases (Sarikaya et al. 2000). Plant $\beta$-amylases, lacking the characteristic " $\mathrm{C}$ terminal-all-beta" sheet domains, also lack the ability to digest raw starch.

In this study, the Amyl gene was also cloned in pYLSC vector, which includes additional signal peptide encoded within the vector's sequence and drives the recombinant gene expression from a hp4d strong hybrid promoter. The vector targets insertion of the cloned gene in the pBR322 docking platform that is contained within the compatible $Y$. lipolytica Polg strain's genome in a single copy. We screened the obtained transformant strains for the copy number of the recombinant Amyl gene, using real-time PCR technique. The selected strain, Y. lipolytica 1.18, with an estimated four copies of the recombinant Amyl gene (the relative quantitation value $\Delta \Delta \mathrm{C}_{\mathrm{T}}$ was 4.17 calculated vs. Polg parental strain), was further used in this study.

Production of the $\alpha$-amylase in $Y$. lipolytica 1.18 strain and purification through affinity chromatography

The recombinant $\alpha$-amylase was produced by the $Y$. lipolytica 1.18 strain in a growth-dependent manner, without the need for induction with starch. The culture medium contained glycerol as the sole carbon source. Elimination of glucose, or any other sugar, from the medium recipe, was convenient for the amylase assay, as the background sugar level was relatively low. Importantly, most of the $\alpha$-amylase activity was detected in the culture medium, confirming that the protein was efficiently targeted to the secretory pathway of the yeast cells (Fig. 1), which greatly facilitated the subsequent purification step. The recombinant $\alpha$-amylase activity in the culture medium was observed after only $29 \mathrm{~h}$ of culturing, immediately after entering the stationary phase of growth. The production of the recombinant $\alpha$-amylase secreted into the culture medium reached the maximum value of $81 \mathrm{AU} / \mathrm{L}$, at the volumetric and specific productivity of $2.8 \mathrm{AU} / \mathrm{L} \mathrm{h}$ and $2.56 \mathrm{AU} / \mathrm{gDCW}$, respectively (Table 2). A minor fraction of the $\alpha$-amylase activity was detected inside the cells (23 AU/L, $0.79 \mathrm{AU} / \mathrm{L} \mathrm{h}$, and $0.72 \mathrm{AU} / \mathrm{gDCW}$ ).

Purification of the recombinant $\alpha$-amylase was carried out through precipitation of total protein contained within the culture medium with ammonium sulfate, followed by affinity chromatography. Overall 25-fold purification was achieved with $5 \%$ yield, resulting in $2.54 \mathrm{mg}$ of purified $\alpha$-amylase activity, in the two-step procedure (Table 3 ). It was possible to purify the enzyme to apparent homogeneity, visualized by SDS-PAGE, through this simple procedure. The purification process was monitored through SDS-PAGE (Fig. 2). The purified recombinant $\alpha$-amylase migrated as a single band of approximately $53 \mathrm{kDa}$, as predicted from the translated nucleotide sequence. Native PAGE analysis of both the medium protein precipitate and the purified $\alpha$-amylase fraction revealed the presence of a single amylolytic isozyme, with no interfering activities present.

\section{Characterization of the purified amylase}

The purified recombinant $\alpha$-amylase was tested for optimal $\mathrm{pH}$ and temperature and also for the $\mathrm{Ca}^{2+}$ ion requirement. 


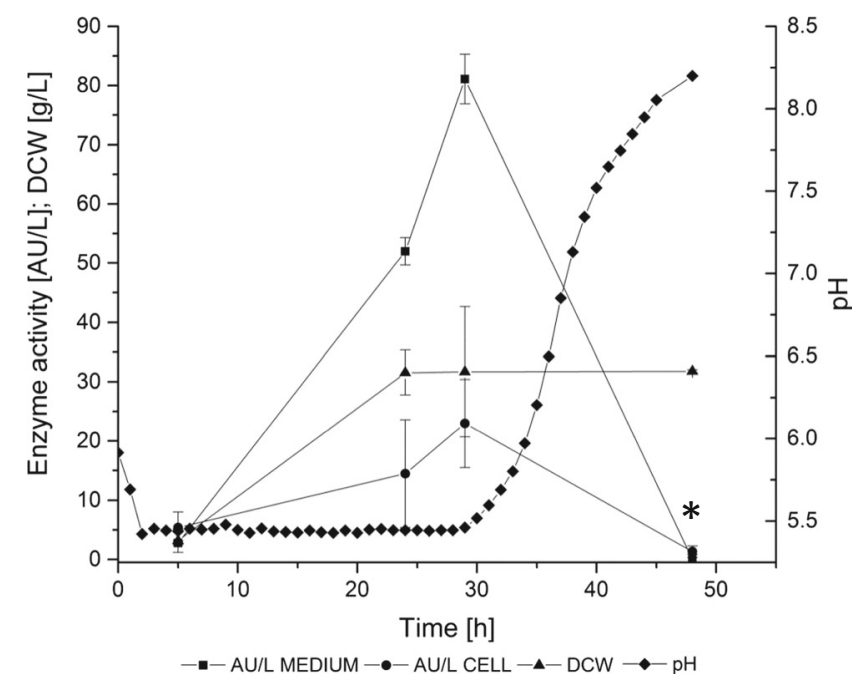

Fig. $1 \alpha$-Amylase production in batch bioreactor cultures of $Y$. lipolytica 1.18 strain. The cultures were carried out in a 5-L bioreactor, with a working volume of $2 \mathrm{~L}$, in YPG-rich medium, at $\mathrm{pO}_{2} 30 \%$; $\mathrm{pH}$ was adjusted to 5.5 by the addition of alkali. Amylase activity was determined in raw medium (closed squares) and protein extract from the cells (closed circles), according to the Nelson-Somogyi method. [DCW]: dry cellular weight was determined by gravimetric method (closed triangle). $x$-axis: time of culture $[\mathrm{h}] ; y$-axis left: $[\mathrm{AU} / \mathrm{L}]$ : activity units per liter of the culture medium; [DCW] expressed in [g/L]. y-axis right: $\mathrm{pH}$ (closed diamonds). Asterisk marks a decrease in the $[\mathrm{AU} / \mathrm{L}]$ parameter attributed to elevated $\mathrm{pH}$. The culture was carried out in three independent runs. All the measurements were done in three technical replicates for each culture. Error bars indicate \pm SD from the three independent runs

The optimal conditions for the $\alpha$-amylase activity were $\mathrm{pH} 5.0$ and temperature of $40^{\circ} \mathrm{C}$ (Fig. 3). The $\alpha$-amylase studied here did not show any obligate requirement for metal ions, as no apparent increase in activity was observed with $\mathrm{Ca}^{2+}$ cation provision $(0.82 \pm 0.06$ vs. $0.79 \pm 0.05$ of released reducing sugar equivalents with and without $\mathrm{Ca}^{2+}$, respectively; $\pm \mathrm{SD}$ ).

Eleven species of raw starch granules of different botanical origin were tested for digestibility by the purified $\alpha$-amylase (Fig. 4). As expected, the substrates varied significantly in the degree of decomposition by the enzyme, which obviously

Table 2 Productivity and specific productivity of the recombinant $\alpha$ amylase production by $Y$. lipolytica 1.18 strain in bioreactor batch cultures

\begin{tabular}{clll}
\hline & {$[\mathrm{AU} / \mathrm{L} \mathrm{h}] \pm \mathrm{SD}$} & {$[\mathrm{AU} / \mathrm{gDCW}] \pm \mathrm{SD}$} & {$[\mathrm{AU} / \mathrm{gDCW} \mathrm{h}] \pm \mathrm{SD}$} \\
\hline $\begin{array}{clll}\text { Medium } \\
5 \mathrm{~h}\end{array}$ & $0.56 \pm 0.07$ & $0.88 \pm 0.11$ & $0.18 \pm 0.02$ \\
$24 \mathrm{~h}$ & $2.17 \pm 0.09$ & $1.65 \pm 0.07$ & $0.07 \pm 0.003$ \\
$29 \mathrm{~h}$ & $2.8 \pm 0.14$ & $2.56 \pm 0.13$ & $0.09 \pm 0.004$ \\
$48 \mathrm{~h}$ & $0 \pm 0.01$ & $0.00 \pm 0.02$ & $0.00 \pm 0.0005$ \\
Pellet & & & \\
$5 \mathrm{~h}$ & $1.1 \pm 0.51$ & $1.70 \pm 0.81$ & $0.34 \pm 0.16$ \\
$24 \mathrm{~h}$ & $0.60 \pm 0.37$ & $0.46 \pm 0.28$ & $0.02 \pm 0.01$ \\
$29 \mathrm{~h}$ & $0.79 \pm 0.25$ & $0.72 \pm 0.23$ & $0.025 \pm 0.008$ \\
$48 \mathrm{~h}$ & $0.03 \pm 0.02$ & $0.031 \pm 0.04$ & $0.00 \pm 0.0009$ \\
\hline
\end{tabular}

resulted from varying sizes and structures of the granules, but also from different contents of amylose/amylopectin in the respective substrates. Surprisingly, the highest decomposition degree was observed for the pea starch, followed by amaranth, waxy rice, and waxy corn $(0.44 \pm 0.004,0.12 \pm$ $0.004,0.11 \pm 0.01$, and $0.01 \pm 0.0001 \mu \mathrm{mol}$ of reducing sugar equivalents, respectively; $\pm \mathrm{SD}$ ), with no detectable degradation of granular starch originating from potato, tapioca (both starches characterized by a high degree of amylose polymerization), wheat, or amylose-containing corn. It has been reported that pea flour is a strong repellent of S. oryzae, which makes it a promising protecting agent of stored rice and wheat grains (Pretheep-Kumar et al. 2004). However, it has been observed that pure pea starch is not the repelling agent, but rather pea proteins, contained in the pea flour, exert the repelling effect. Our studies indicate that pea starch in its native, granular form can be efficiently decomposed by the digestive enzyme synthesized in the alimentary tract of $S$. oryzae.

With respect to decomposition of liquefied starch, most of the tested substrates were digested on a similar level ( 0.26 to $0.41 \mu \mathrm{mol}$ of reducing sugar equivalents), apart from waxy corn, corn, and pea, which were digested to a slightly smaller degree ( 0.13 to $0.22 \mu \mathrm{mol}$ of reducing sugar equivalents) (Fig. 4). Surprisingly, wheat starch was not digested even in liquefied form, which obviously indicates the presence of some proteinaceous inhibitors.

SEM micrographs confirmed the observations from the enzymatic assay (Fig. 5). Pea and amaranth starch granules appeared like drilled through, presenting extensive erosion in their interior, with no formation of pits and craters on the surface, showing centripetal type of degradation by the $\alpha$ amylase. Waxy corn and waxy rice granules were digested by the amylase by creating small shallow pits and crater-like areas on the surface of the granules. Wheat and soluble potato starch remained intact after the $\alpha$-amylase treatment.

\section{Discussion}

Amylolytic enzymes are one of the most important industrially relevant enzymes, accounting for approximately $30 \%$ of the world's production of enzymes (van der Maarel et al. 2002). Despite of the wide distribution of amylases among plant, animal, and microbial species, only fungal and bacilli enzymes constitute a significant contribution to the world's market. Other sources are significantly less explored. For most insect species studied to date, information on the raw-starchdigesting enzymes has been very scarce. The main factor limiting the progress within this field is a laborious, inefficient, and multistep procedure for the isolation and purification of enzymes from small animals. Heterologous overexpression offers the possibility to surpass these constraints. 
Table 3 Purification of the recombinant $\alpha$-amylase from $Y$. lipolytica 1.18 bioreactor culture

\begin{tabular}{lllllllll}
\hline Purification step & $\begin{array}{l}\text { Activity } \\
{[\mathrm{AU} / \mathrm{L}]}\end{array}$ & $\begin{array}{l}\text { Volume } \\
{[\mathrm{mL}]}\end{array}$ & $\begin{array}{l}\text { Total activity } \\
{[\mathrm{AU}]}\end{array}$ & $\begin{array}{l}\text { Protein } \\
{[\mathrm{mg} / \mathrm{mL}]}\end{array}$ & $\begin{array}{l}\text { Total protein } \\
{[\mathrm{mg}]}\end{array}$ & $\begin{array}{l}\text { Specific activity } \\
{[\mathrm{AU} / \mathrm{mg}]}\end{array}$ & $\begin{array}{l}\text { Yield } \\
{[\%]}\end{array}$ & $\begin{array}{l}\text { Purification } \\
\text { factor [fold] }\end{array}$ \\
\hline $\begin{array}{l}\text { Crude medium } \\
\begin{array}{l}\text { Ammonium sulfate } \\
80 \%+\text { affinity chromatography }\end{array}\end{array}$ & 84.24 & 700 & 58.97 & 1.84 & 1290.06 & 0.05 & 1.00 & 1.00 \\
& 481.67 & 6 & 2.89 & 0.42 & 2.54 & 1.14 & 5 & 24.91 \\
\hline
\end{tabular}

In this study, $Y$. lipolytica was exploited as the host for expression of insect ( $S$. oryzae) $\alpha$-amylase, to investigate its potential usefulness in raw starch digestion. Y. lipolytica Po1g strain was transformed with pYLSC-Amyl expression cassette, intended for integration into the host genome. Integration of the expression cassette with the host genome offers a significant advantage over the episomal expression platforms. This is particularly true for Y. lipolytica, as really potent episomal plasmids are currently just being developed (Liu et al. 2014). Integrative expression cassettes are more stable and eliminate the necessity of selection pressure maintenance, which is of significant importance during large-scale and/or prolonged cultivations in complex, nondefined media. Our complementary experiments showed significant improvement

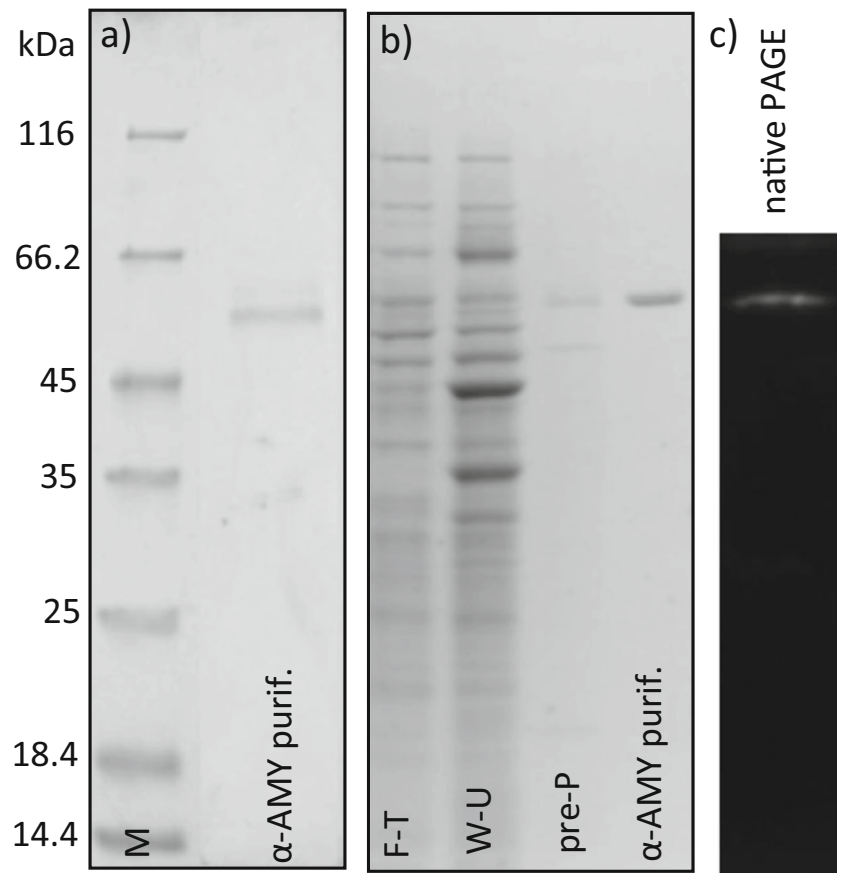

Fig. 2 SDS-PAGE and native PAGE separation of protein samples. a SDS-PAGE separation of purified $\alpha$-amylase after ammonium sulfate precipitation and affinity chromatography with a molecular mass marker $(M$; unstained protein molecular weight marker, Thermo Scientific). b SDS-PAGE electrophoretic separation of fractions after affinity chromatography; $F-T$ flow-through, $W$ - $U$ wash-unbound, pre- $P$ pre-peak with low $\alpha$-amylase activity, $\alpha$-AMY purif. fraction with the highest $\alpha$-amylase activity. c Native PAGE electrophoretic separation of $\alpha$-amylase-containing enzymatic preparation; the gel contained $1 \%$ of liquefied starch; after separation, the gel was incubated $\mathrm{O} / \mathrm{N}$ in $\mathrm{Ca}^{2+} / \mathrm{NaCl}$ acetate buffer and afterward stained with iodine in the AMY protein production by the 1.18 strain in the rich medium (YPG), when compared to the production in the minimal medium, enabling selection pressure maintenance (YNB, with glycerol at $20 \mathrm{~g} / \mathrm{L}$ as a carbon source; data not shown). Therefore, the bioreactor cultivations were all carried out in the rich YPG medium.

To select a single clone for the production of the recombinant $\alpha$-amylase, the transformants were screened for estimated copy number of the heterologous Amyl gene, using realtime PCR technique. As demonstrated by Nicaud et al. (2002), the heterologous gene copy number was a strong determinant of the amount of an enzyme produced, contributing to up to 8fold increase in the enzyme activity, solely due to gene amplification. The technique applied in this study indicated the presence of 4 copies of the Amyl gene per genome of $Y$. lipolytica 1.18 strain. However, further studies are necessary to confirm this observation and reveal the mode of the cassette integration (tandem or random, out of site), as integration of higher number of copies is rather surprising in the strain Po1g-pYLSC1 system. Although recent papers state that $Y$. lipolytica is known to preferentially use the nonhomologous end-joining mechanism for DNA repair over homologous recombination (Kretzschmar et al. 2013; Verbeke et al. 2013), which could potentially explain the integration of a higher number of copies of the expression cassette than the number of potential integration sites (single pBR322 docking platform per Po1g strain's genome), it was also reported that out-of-site integrations are rare events in Y. lipolytica (Madzak et al. 2000). In the first report describing hp4d promoter, similar pBR-based vectors were used, several tens of transformants were analyzed by Southern blotting, and only one example of a double tandem integration (at the intended pBR docking platform) was identified (Madzak et al. 2000). According to the review by Barth and Gaillardin (1996), when using a sufficiently large region of homology (more than $300 \mathrm{bp}$ on each side - which is significantly less than in the pYLSC1 vector), a single complete copy of the expression cassette integrates at the chosen site in more than $80 \%$ of the cases, while the remaining events include multiple tandem integrations, gene conversions, and out-of site integrations.

The recombinant $\alpha$-amylase production by the $Y$. lipolytica 1.18 strain during the bioreactor batch cultivations was very rapid. As indicated in Fig. 1, the peak value in the recombinant $\alpha$-amylase activity was reached immediately after entering the 


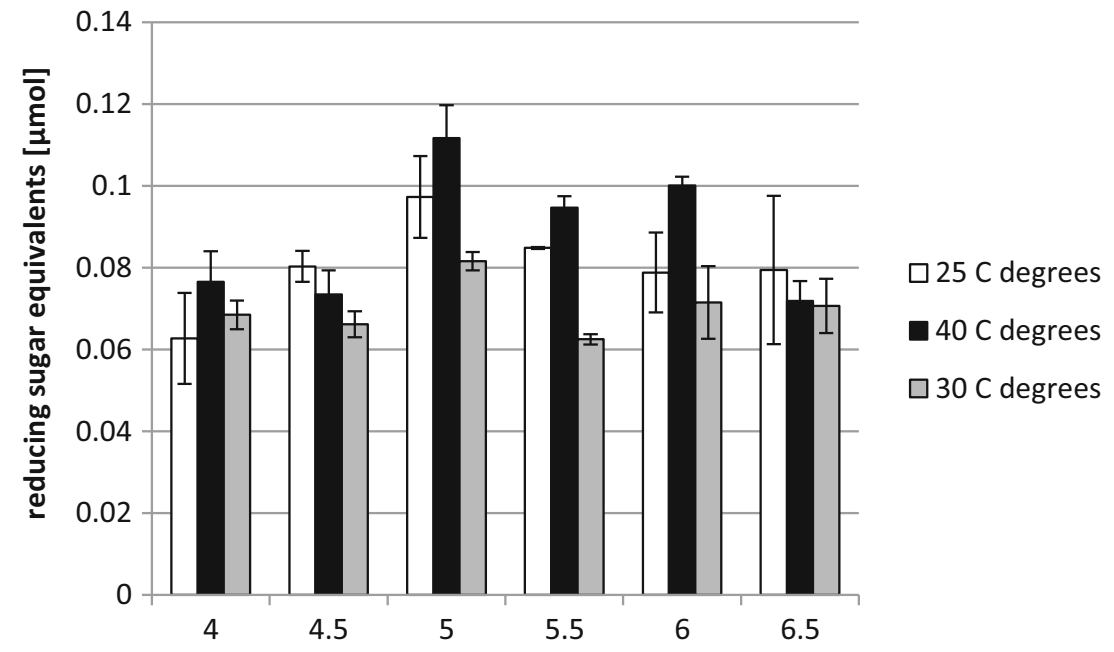

Fig. $3 \alpha$-Amylase activity at different $\mathrm{pH}$ values and temperatures. Liquefied starch solution in $100 \mathrm{mM}$ acetate buffer (for $\mathrm{pH}$ 4.0, 4.5, 5.0, 5.5) or $100 \mathrm{mM}$ phosphate buffer (for $\mathrm{pH} 6.0$ and 6.5) was used as the reaction substrate. The assay was carried out according to the Nelson-

stationary phase of growth. Importantly, during the next timepoint interval, we observed a significant decrease in the enzyme activity. The observed drop in the recombinant $\alpha$ amylase activity could be possibly attributed to a rapid increase in the $\mathrm{pH}$ value. Probably, the high $\mathrm{pH}$ value was detrimental to the heterologous $\alpha$-amylase activity assessment, since at $\mathrm{pH} \sim 8.0$, the activity was not detectable, both in the cell and in the medium. Noteworthy, we were still able to recover the $\alpha$-amylase from the end-point culture medium after the purification procedure, through ammonium sulfate precipitation and affinity chromatography, which demonstrates that the protein was still present in the medium. Also, previous reports on heterologous enzyme production within the Y. lipolytica-hp4d promoter-based expression systems showed continued accumulation of the proteins during the stationary growth phase rather than a peak value followed
Somogyi method, under varied thermal conditions: 25,30 , and $40{ }^{\circ} \mathrm{C}\left({ }^{\circ} \mathrm{C}\right.$ marked as " $\mathrm{C}$ degrees" in the figure). $y$-axis: reducing sugar equivalents released under the assay conditions in micromoles. Error bars indicate \pm SD from triplicate measurements

by a decrease in activity (Madzak et al. 2005; Yang et al. 2010a). According to the characteristics provided by Madzak et al. (2004), hp4d recombinant promoter is almost independent from environmental conditions and is able to drive a strong expression in virtually any medium, promoting growth-phase-dependent gene expression. It was found that hp4d-driven heterologous gene expression occurs mostly at the beginning of the stationary phase (Nicaud et al. 2002), which we have also observed in our study. However, the increase in the $\mathrm{pH}$ value obviously hampered further accumulation of the recombinant $\alpha$-amylase.

When compared with the literature data, the $\alpha$-amylase activity was detected relatively fast. Huang et al. (2011), using the same expression system, observed peak activity of esterase after $72 \mathrm{~h}$ of fed-batch culture. A similar time (60-72 h) was required for the maximal invertase production by recombinant

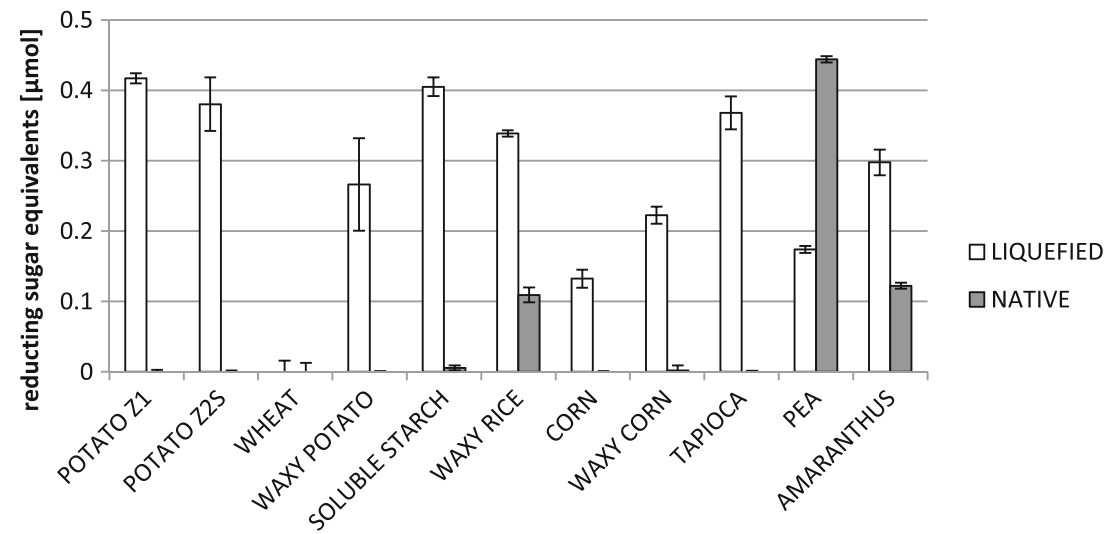

Fig. 4 Digestibility of different starch species by recombinant $\alpha$-amylase enzymatic preparation. Starch was provided as $1 \%$ solution in $100 \mathrm{mM}$ acetate buffer, $\mathrm{pH}$ 5.0. The reaction mixture was incubated at $40{ }^{\circ} \mathrm{C}$ for $30 \mathrm{~min}$ with $0.386 \mathrm{mAU}$ of $\alpha$-amylase or $1 \mathrm{~h}$ with $36.8 \mathrm{mAU}$ of $\alpha$ - amylase for liquefied and native substrates, respectively. $y$-axis: reducing sugar equivalents released under the assay conditions in micromoles. Error bars indicate \pm SD from triplicate measurements 
Y. lipolytica strains (Förster et al. 2007; Lazar et al. 2011). Boisramé and Gaillardin (2009) observed production of a recombinant $\beta$-1,6-glucanase in $Y$. lipolytica Polg strain after $60 \mathrm{~h}$ of culturing. In our complementary experiments, we used minimal, defined medium (YNBG; glycerol at $100 \mathrm{~g} / \mathrm{L}$ instead of glucose) in the bioreactor cultures, which resulted in the peak value in the heterologous $\alpha$-amylase activity after $72 \mathrm{~h}$ of culturing (data not shown). Therefore, the rapid character of the culture could be attributed to the use of a rich, nonselective medium. Correspondingly, a rapid production trend has been observed for recombinant $Y$. lipolytica strain expressing heterologous fatty acid hydroperoxide lyase, where the maximum of the enzyme activity was observed after $24 \mathrm{~h}$ of culturing (Santiago-Gómez et al. 2007). While in the earlier study of Bourel et al. (2004), the peak activity of fatty acid hydroperoxide lyase expressed in $Y$. lipolytica was observed in the stationary phase of growth (between 86 and $92 \mathrm{~h}$ of culturing).

Most of the produced $\alpha$-amylase was secreted into the culture medium; however, the obtained amount of the enzyme remains to be further optimized. The amount of fatty acid hydroperoxide lyase expressed in Y. lipolytica strain in rich medium was $2500 \mathrm{AU} / \mathrm{L}$, but the enzyme was retained within the cells (Santiago-Gómez et al. 2007); 4000 AU of rice $\alpha$ amylase per liter of crude medium was reported by Park et al. (1997). This result was further improved by optimization of the culturing mode (Chang et al. 1998; Kim et al. 2000; discussed below). In another paper, heterologous expression of thermostable microbial $\alpha$-amylase in $Y$. lipolytica host has been reported (Yang et al. 2010a). The enzyme was produced at a high yield of 730 AU/L. Comparison with the authors' previous studies, where the same gene was expressed in P. pastoris (Yang et al. 2010b) and E. coli (Yang and Liu 2007), proved $Y$. lipolytica-pYLSC1 host to be the superior expression system over the other two analyzed. Förster et al. (2007) and Lazar et al. (2011) produced invertase in recombinant $Y$. lipolytica cells, but the reported activity units per milliliter values differed significantly, with 105 and 589 U/ gDCW of extracellular fraction, respectively. In the study by Lazar et al. (2011), very high and rapid invertase production was observed (300 to $442 \mathrm{U} / \mathrm{L} \mathrm{h}$ ), but the intracellular enzyme fraction was significantly higher (up to $3736 \mathrm{U} / \mathrm{gDCW}$ ). Although the ultimate values of the results cited above cannot be directly compared, due to different enzymatic activities being determined, it appears that the potential of Y. lipolytica was not fully explored in this study, and further research on improvement of the recombinant $\alpha$-amylase production will be carried out. As demonstrated by Nicaud et al. (2002), fed-batch cultures were highly beneficial for overexpression of heterologous proteins in Y. lipolytica strains, as illustrated by 7.9-fold or 11-fold increase in lipase and leucine amino peptidase production, respectively, when compared to batch cultures. In another study, rice $\alpha$-amylase was efficiently produced in
Y. lipolytica transformant using cyclic fed-batch culture mode, reaching high cell density culture (Chang et al. 1998). Due to intensification of the culturing process, it was possible to obtain as high volumetric productivity of the enzyme as $1960 \mathrm{AU} /(\mathrm{L} \mathrm{h})$. In the same paper, the authors describe fedbatch culture, where $31,200 \mathrm{AU} / \mathrm{L}$ of $\alpha$-amylase was obtained. The rice $\alpha$-amylase production process was further improved in the following study by the same research team (Kim et al. 2000). Using a single feeding step with concentrated substrate into the batch culture, the authors obtained a high cell density culture of the recombinant $Y$. lipolytica (over $100 \mathrm{~g} \mathrm{DCW} / \mathrm{L}$ ) with the final $\alpha$-amylase activity of 88 , $000 \mathrm{AU} / \mathrm{L}$.

Extracellular localization of the recombinant proteins is highly advantageous for the subsequent purification strategies. In this study, due to majority of the enzyme being secreted into the culture medium, we were able to apply a relatively simple two-step purification procedure. Through ammonium sulfate precipitation followed by affinity chromatography, it was possible to purify the enzyme to apparent homogeneity, with 25-fold purification factor at $5 \%$ yield. Depending on the microbial producer and the applied purification method, RSD amylases could be purified by 2.8- or 8.5fold at 12 or $60.5 \%$ yield from Aspergillus sp. (Okolo et al. 2001), 6-fold at 38 \% yield from Bacillus licheniformis (Božić et al. 2011), 5.4-fold at $72.9 \%$ yield from Rhizopus sp. (Morita et al. 1998), or by 34-fold at $6.6 \%$ yield from Bacillus sp. (Liu and $\mathrm{Xu}$ 2008). In a recent paper, Kumar and Khare (2012) in a three-step purification procedure obtained 76-fold purification at $52 \%$ yield of halophilic $\alpha$-amylase from its native producer, Marinobacter sp. Single step purification, through in-batch addition of affinity resin, was applied to $\beta$ 1,6-glucanase secreted into the medium by recombinant Y. lipolytica; however, no purification factor and yield were reported (Boisramé and Gaillardin 2009). Santiago-Gómez et al. (2007) purified fatty acid hydroperoxide lyase through extraction of the enzyme from the cells with Triton X-100R ( $2 \%$ ) followed by IMAC chromatography. The initial amount of the enzyme in crude extract was $2500 \mathrm{AU} / \mathrm{L}$, and after purification of $29 \mathrm{AU} / \mathrm{L}$, resulting in $28.1 \mathrm{mg}$ of the purified enzyme. Rice $\alpha$-amylase was purified from the culture medium of recombinant $Y$. lipolytica by ammonium sulfate precipitation at $75 \%$ saturation and subsequently subjected to $\beta$ cyclodextrin affinity chromatography, resulting in 72-fold purification at $47 \%$ yield (Park et al. 1997). In a study by Madzak et al. (2005), heterologous laccase was produced in $Y$. lipolytica, and the purification factor after the five-step purification process (including ultrafiltration of FPLC chromatography) was of 74-fold, with a recovery of $26 \%$, yielding $0.7 \mathrm{mg}$ of purified recombinant laccase. Heterologous $\alpha$ amylase from $T$. fusca produced in Y. lipolytica was purified 10-fold at $21.87 \%$ yield, using a three-step procedure (Yang et al. 2010a). Lazar et al. (2011) concentrated and purified 
invertase produced by Y. lipolytica by approximately 5 - to 10fold through ultrafiltration. In general, ultrafiltration appears to be one of the most efficient methods of protein concentration from the medium prior to chromatography step, as the reported purification factors and yields compare favorably with the ammonium sulfate-based strategies, e.g., 400-fold purification at $64 \%$ yield from Bacillus firmus (Gawande et al. 1999), 141-fold purification at $78 \%$ yield from Cryptococcus sp. (Iefuji et al. 1996), or 738 -fold purification at $68 \%$ yield from Klebsiella pneumoniae (Gawande and Patkar 2001). In this study, a significant loss in the amount of the enzyme purified from the medium was attributed to low efficiency of the ammonium sulfate precipitation step.

The purified $\alpha$-amylase was subsequently characterized with respect to some of its main characteristics. The optimal conditions for the $\alpha$-amylase activity were $\mathrm{pH} 5.0$ and temperature of $40{ }^{\circ} \mathrm{C}$. The optimum activity of amylolytic enzymes around $\mathrm{pH}$ of $4.5-5.0$ is highly desirable, since in the starch industry, the natural $\mathrm{pH}$ of starch slurry is usually around 4.5 (Sivaramakrishnan et al. 2006). Most of the commercial bacterial $\alpha$ amylases are highly active at $\mathrm{pH} 6.5$ and are unstable in an acidic environment, thus causing the necessity of the slurry pH adjustment (Sajedi et al. 2005). Employment of amylolytic enzymes that are stable and highly active under acidic conditions could simplify the starch processing pipeline. The $\alpha$-amylase studied here did not show any obligate requirement for $\mathrm{Ca}^{2+}$ ions. A similar property was reported for amylase from Bacillus amyloliquefaciens (Gangadharan et al. 2009). According to Baker (1987), amylases isolated from $S$. oryzae guts, like a number of typical amylases, are activated by $\mathrm{Ca}^{2+}$ and $\mathrm{Cl}^{-}$ions (assayed in acetate buffer pH 5.0, $20 \mathrm{mM} \mathrm{NaCl}, 0.1 \mathrm{mM}$ $\left.\mathrm{CaCl}_{2}\right) . \mathrm{Ca}^{2+}$ ions are known to exert a stabilizing effect on elevated temperature-treated RSDE, by endowing them with a more compact structure. Similarly, greater thermal stability of RSD amylases has been observed under provision of carbohydrate substrate.

In the pioneering studies by Baker and Woo (1992), $\alpha$ amylase isozymes isolated from the digestive tract of $S$. oryzae were tested on various substrates, including raw starch granules. It was found that corn and wheat starch granules were rather resistant to the action of amylases, while rice starch was relatively prone to digestion (4- and 6-fold more susceptible, when compared to corn and wheat starch, respectively). However, among commercial starch samples, granular potato starch was the most resistant to $\alpha$ amylases from $S$. oryzae, which stays in full agreement with our observations. Relative to granular potato starch, activity against other tested starches ranged from 2-fold greater for tapioca starch to nearly 16 -fold greater for corn starch, which again complies well with our results, since under applied conditions, tapioca native starch was found
Fig. 5 Scanning electron micrographs of various starch granules digested with the recombinant $\alpha$-amylase. Digestion was carried out according to the procedure described in the section "Testing various starch types for digestibility by the new amylase," and samples were prepared according to the procedure described in the section "Scanning electron microscopy." Starch types: 1. potato, 2. waxy rice, 3. waxy corn, 4. pea, 5 . amaranth, 6 . wheat. $A$. nontreated sample, $B$, treated sample. White arrows indicate signs of $\alpha$-amylase action

to be resistant to enzymatic degradation. Potato starch was also found to be the most resistant against digestion, when treated with $\alpha$-amylase from $B$. amyloliquefaciens (Sarikaya et al. 2000), while cereal starches (rice, corn, and wheat) were easily decomposed by this enzyme. Corn, wheat, and potato starch granules were tested for digestibility by $\alpha$-amylase from Bacillus sp. YX-1, showing a similar degree of decomposition $(57.5,53$, and $45 \%$, respectively) (Liu and Xu 2008). Importantly, we tested the raw starch digestibility in an assay lasting for only $1 \mathrm{~h}$ with relatively small amounts of the enzyme preparation ( $40 \mathrm{mAU})$, while a number of assays were continued for 8 to $12 \mathrm{~h}$, with $50 \mathrm{AU}$ per reaction (Liu and Xu 2008), 12 to $24 \mathrm{~h}$ (Sarikaya et al. 2000; AU were not reported), and 12 to $48 \mathrm{~h}$, with $0.5 \mathrm{AU}$ per reaction (Meireles et al. 2009). Significant degradation of the starch granules, especially observed for pea and amaranth starches, in a short time and in the presence of small quantities of the enzyme, demonstrates high potential of the $\alpha$-amylase to digest nonpretreated, raw substrate. Surprisingly, we have observed that wheat starch has not been digested either in native or liquefied form. High antagonistic activity of an $\alpha$-amylase inhibitor (WRP-25) in wheat starch toward amylase isozymes isolated from the guts of three insect species (i.e., S. oryzae) has been reported by Chen et al. (1992). Detailed studies on the interaction of $\alpha$-amylase from $S$. oryzae and 0.12 inhibitor from wheat have been reported by Baker (1989). Our results concerning wheat starch indigestibility by the $\alpha$-amylase from $S$. oryzae could be probably attributed to the presence of the inhibitors in the analyzed substrate.

In conclusion, $Y$. lipolytica appeared to be a good host for the expression and efficient secretion of heterologous $\alpha$-amylase from phylogenetically distant $S$. oryzae. Bioreactor cultures were very rapid (peak activity at $29 \mathrm{~h}$ ), but further optimization of the process efficiency will be carried out. Purified $\alpha$-amylase was most active at slightly acidic conditions ( $\mathrm{pH}$ 5.0), without obvious requirement for $\mathrm{Ca}^{2+}$ ions. Importantly, it was found that the enzyme was able to efficiently digest several types of raw, granular starch, in a short time, which is of great potential for industrial applications. Our further efforts will be focused on the optimization of the $\alpha$-amylase production process. 


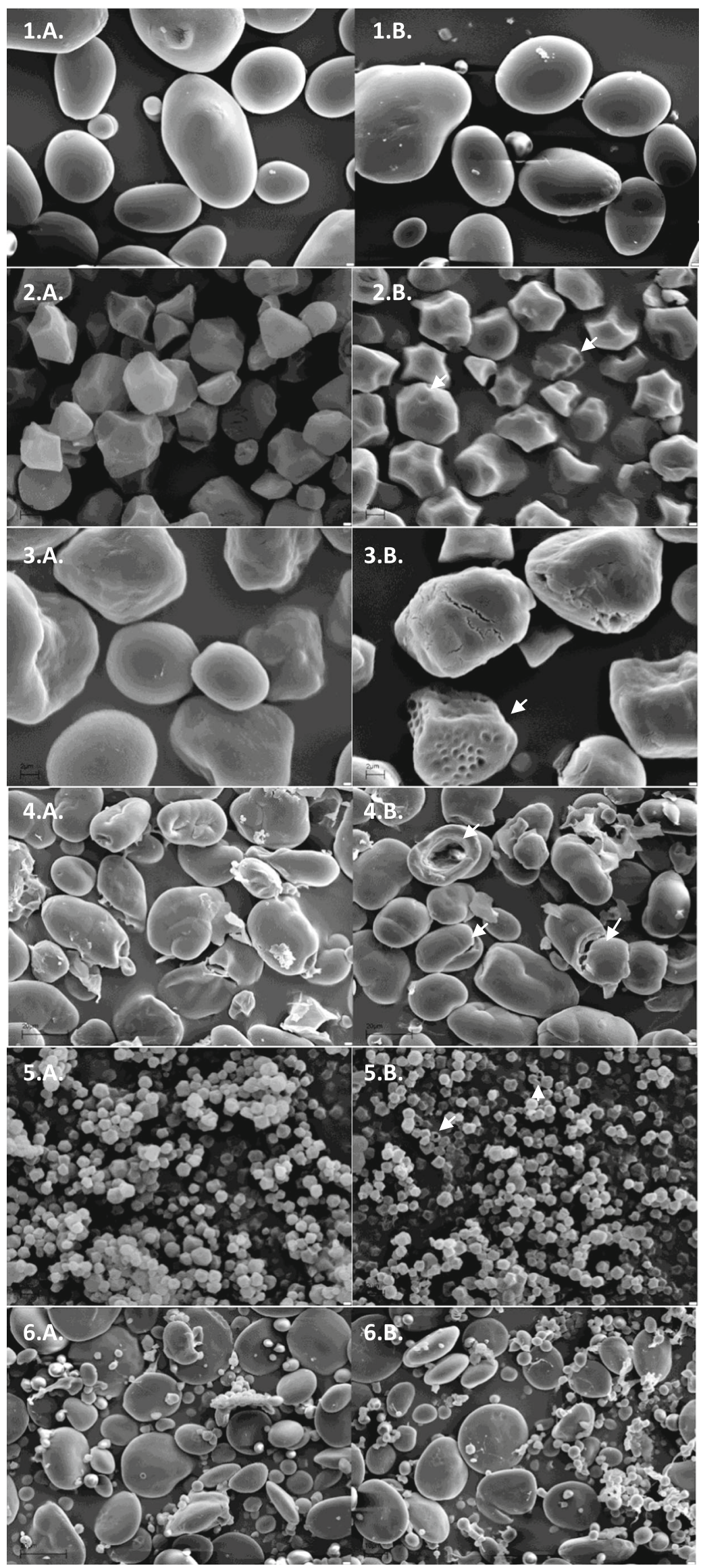


Acknowledgments This study was carried out within the framework of the project number 2012/05/N/NZ1/00002, entitled "Heterologous expression of alpha-amylase gene in recombinant yeast Yarrowia lipolytica," financially supported by the National Science Center, Poland.

Conflict of interest The authors declare no financial or commercial conflict of interest.

Open Access This article is distributed under the terms of the Creative Commons Attribution License which permits any use, distribution, and reproduction in any medium, provided the original author(s) and the source are credited.

\section{References}

Baker JE (1987) Purification of isoamylases from the rice weevil, Sitophilus oryzae (L.) (Coleoptera: Curculionidae), by highperformance liquid chromatography and their interaction with partially-purified amylase inhibitors from wheat. Insect Biochem 17:37-44

Baker JE (1989) Interaction of inhibitor-0.12 from wheat with two amylase isozymes from the rice weevil, Sitophilus oryzae (Coleoptera: Curculionidae). Comp Biochem Physiol B 92:389-393

Baker JE, Woo SM (1992) Digestion of starch granules by $\alpha$-amylases from the rice weevil, Sitophilus oryzae: effect of starch type, fat extraction, granule size, mechanical damage, and detergent treatment. Insect Biochem Mol 22:529-537

Barth G, Gaillardin C (1996) Yarrowia lipolytica. In: Wolf K (ed) Nonconventional yeasts in biotechnology, A handbook. Springer, Berlin, pp 313-388

Białas W, Celińska E, Dembczyński R, Szymanowska D, Nowacka M, Jesionowski T, Grajek W (2013) Cross-flow microfiltration of fermentation broth containing native corn starch. J Membr Sci 427: $118-128$

Boisramé A, Gaillardin C (2009) Heterologous expression and characterization of a beta-1,6-glucanase from Aspergillus fumigatus. Appl Microbiol Biotechnol 82:663-669

Bourel G, Nicaud JM, Nthangeni B, Santiago-Gomez P, Belin JM, Husson F (2004) Fatty acid hydroperoxide lyase of green bell pepper: cloning in Yarrowia lipolytica and biogenesis of volatile aldehydes. Enzym Microb Technol 35:293-299

Božić N, Ruiz J, López-Santín J, Vujčić Z (2011) Production and properties of the highly efficient raw starch digesting $\alpha$-amylase from a Bacillus licheniformis ATCC 9945a. Biochem Eng J 53:203-209

Bradford MM (1976) A rapid and sensitive method for the quantitation of microgram quantities of protein utilizing the principle of protein-dye binding. Anal Biochem 72:248-254

Celińska E, Grajek W (2013) A novel multigene expression construct for modification of glycerol metabolism in Yarrowia lipolytica. Microb Cell Factories 12:102

Chang CC, Ryu DD, Park CS, Kim JY (1998) Improvement of heterologous protein productivity using recombinant Yarrowia lipolytica and cyclic fed-batch process strategy. Biotechnol Bioeng 59:379-385

Chen MS, Feng G, Zen KC, Richardson M, Valdes-Rodriguez S, Reeck GR, Kramer KJ (1992) $\alpha$-Amylases from three species of stored grain Coleoptera and their inhibition by wheat and corn proteinaceous inhibitors. Insect Biochem Mol 22:261-268

Demirkan ES, Mikami B, Adacji M, Higasa T, Utsumi S (2005) $\alpha$ Amylase from $B$. amyloliquefaciens: purification, characterization, raw starch degradation and expression in E. coli. Process Biochem 40:2629-2636
Förster A, Aurich A, Mauersberger S, Barth G (2007) Citric acid production from sucrose using a recombinant strain of the yeast Yarrowia lipolytica. Appl Microbiol Biotechnol 75:1409-1417

Gangadharan D, Nampoothiri KM, Sivaramakrishnan S, Pandey A (2009) Biochemical characterization of raw-starch-digesting alpha amylase purified from Bacillus amyloliquefaciens. Appl Biochem Biotechnol 158:653-662

Gawande BN, Patkar AY (2001) Purification and properties of a novel raw starch degrading-cyclodextrin glycosyltransferase from Klebsiella pneumoniae AS-22. Enzyme Microb Tech 28:735-743

Gawande BN, Goel A, Patkar AY, Nene SN (1999) Purification and properties of a novel raw starch degrading cyclomaltodextrin glucanotransferase from Bacillus firmus. Appl Microbiol Biotechnol 51:504-509

Gellissen G, Kunze G, Gaillardin C, Cregg JM, Berardi E, Veenhuis M, van der Klei I (2005) New yeast expression platforms based on methylotrophic Hansenula polymorpha and Pichia pastoris and on dimorphic Arxula adeninivorans and Yarrowia lipolytica - a comparison. FEMS Yeast Res 5:1079-1096

Grossi de Sa MF, Chrispeels MJ (1997) Molecular cloning of bruchid (Zabrotes subfasciatus) alpha-amylase cDNA and interactions of the expressed enzyme with bean amylase inhibitors. Insect Biochem Mol Biol 27:271-281

Gupta R, Gigras P, Mohapatra H, Goswami VK, Chauhan B (2003) Microbial $\alpha$-amylases: a biotechnological perspective. Process Biochem 38:1599-1616

Hostinová E, Janecek S, Gasperík J (2010) Gene sequence, bioinformatics and enzymatic characterization of alpha-amylase from Saccharomycopsis fibuligera KZ. Protein J 29:355-364

Huang YC, Chen YF, Chen CY, Chen WL, Ciou YP, Liu WH, Yang CH (2011) Production of ferulic acid from lignocellulolytic agricultural biomass by Thermobifida fusca thermostable esterase produced in Yarrowia lipolytica transformant. Bioresour Technol 102:81178122

Iefuji H, Chino M, Kato M, Iimura Y (1996) Raw-starch-digesting and thermostable alpha-amylase from the yeast Cryptococcus sp. S-2: purification, characterization, cloning and sequencing. Biochem $\mathrm{J}$ 318:989-996

Jeang CL, Chen LS, Chen MY, Shiau RJ (2002) Cloning of a gene encoding raw-starch-digesting amylase from a Cytophaga sp. and its expression in Escherichia coli. Appl Environ Microbiol 68: 3651-3654

Jespersen HM, MacGregor EA, Sierks MR, Svensson B (1991) Comparison of the domain-level organization of starch hydrolases and related enzymes. Biochem J 280:51-55

Kim JW, Park TJ, Ryu DD, Kim JY (2000) High cell density culture of Yarrowia lipolytica using a one-step feeding process. Biotechnol Prog 16:657-660

Kretzschmar A, Otto C, Holz M, Werner S, Hübner L, Barth G (2013) Increased homologous integration frequency in Yarrowia lipolytica strains defective in non-homologous end-joining. Curr Genet 59: 63-72

Kumar S, Khare SK (2012) Purification and characterization of maltooligosaccharide-forming $\alpha$-amylase from moderately halophilic Marinobacter sp. EMB8. Bioresour Technol 116:247-251

Laemmli UK (1970) Cleavage of structural proteins during the assembly of the head of bacteriophage T4. Nature 227:680-685

Lazar Z, Walczak E, Robak M (2011) Simultaneous production of citric acid and invertase by Yarrowia lipolytica $\mathrm{SUC}+$ transformants. Bioresour Technol 102:6982-6999

Li S, Zuo Z, Niu D, Singh S, Permaul K, Prior BA, Shi G, Wang Z (2011) Gene cloning, heterologous expression, and characterization of a high maltose-producing $\alpha$-amylase of Rhizopus oryzae. Appl Biochem Biotechnol 164:581-592 
Liu XD, Xu Y (2008) A novel raw starch digesting alpha-amylase from a newly isolated Bacillus sp. YX-1: purification and characterization. Bioresour Technol 99:4315-4320

Liu L, Otoupal P, Pan A, Alper HS (2014) Increasing expression level and copy number of a Yarrowia lipolytica plasmid through regulated centromere function. FEMS Yeast Res. doi:10.1111/1567-1364. 12201

Livak KJ, Schmittgen TD (2001) Analysis of relative gene expression data using real-time quantitative PCR and the 2(-Delta Delta C(T)) method. Methods 25:402-408

Madzak C, Beckerich JM (2013) Heterologous protein expression and secretion in Yarrowia lipolytica. In: Barth G (ed) Yarrowia lipolytica: biotechnological applications, microbiology monographs, vol 25. Springer, Heidelberg, pp 1-76

Madzak C, Tréton B, Blanchin-Roland S (2000) Strong hybrid promoters and integrative expression/secretion vectors for quasi-constitutive expression of heterologous proteins in the yeast Yarrowia lipolytica. J Mol Microbiol Biotechnol 2:207-216

Madzak C, Gaillardin C, Beckerich JM (2004) Heterologous protein expression and secretion in the non-conventional yeast Yarrowia lipolytica: a review. J Biotechnol 109:63-81

Madzak C, Otterbein L, Chamkha M, Moukha S, Asther M, Gaillardin C, Beckerich JM (2005) Heterologous production of a laccase from the basidiomycete Pycnoporus cinnabarinus in the dimorphic yeast Yarrowia lipolytica. FEMS Yeast Res 5:635-646

Matsubara T, Ben Ammar Y, Anindyawati T, Yamamoto S, Ito K, Iizuka M, Minamiura N (2004) Degradation of raw starch granules by alpha-amylase purified from culture of Aspergillus awamori KT11. J Biochem Mol Biol 37:422-428

Meireles EA, Carneiro CB, DaMatta RA, Samuels RI, Silva CP (2009) Digestion of starch granules from maize, potato and wheat by larvae of the yellow mealworm, Tenebrio molitor and the Mexican bean weevil, Zabrotes subfasciatus. J Insect Sci 9:43

Morita H, Matsunaga M, Mizuno K, Fujio Y (1998) A comparison of raw starch-digesting glucoamylase production in liquid and solid cultures of Rhizopus strains. J Gen Appl Microbiol 44:211-216

Müller S, Sandal T, Kamp-Hansen P, Dalbøge H (1998) Comparison of expression systems in the yeasts Saccharomyces cerevisiae, Hansenula polymorpha, Kluyveromyces lactis, Schizosaccharomyces pombe and Yarrowia lipolytica. Cloning of two novel promoters from Yarrowia lipolytica. Yeast 14:1267-1283

Nelson N (1944) A photometric adaptation of the Somogyi method for the determination of glucose. J Biol Chem 153:375

Nicaud JM, Madzak C, van den Broek P, Gysler C, Duboc P, Niederberger P, Gaillardin C (2002) Protein expression and secretion in the yeast Yarrowia lipolytica. FEMS Yeast Res 2:371-379

Okolo BN, Ire FS, Ezeogu LI, Anyanwu CU, Odibo FJC (2001) Purification and some properties of a novel raw starch-digesting amylase from Aspergillus carbonarius. J Sci Food Agric 81:329-336

Pandey A, Nigam P, Soccol CR, Soccol VT, Singh D, Mohan R (2000) Advances in microbial amylases. Biotechnol Appl Biochem 31: $135-152$
Park CS, Chang CC, Kim JY, Ogrydziak DM, Ryu DD (1997) Expression, secretion, and processing of rice alpha-amylase in the yeast Yarrowia lipolytica. J Biol Chem 272:6876-6881

Pretheep-Kumar P, Mohan S, Ramaraju K (2004) Protein-enriched pea flour extract protects stored milled rice against the rice weevil, Sitophilus oryzae. J Insect Sci 4:26

Sajedi RH, Naderi-Manesh H, Khajeh K, Ahmadvand R, Ranjbar B, Asoodeh A, Moradian F (2005) A Ca-independent $\alpha$-amylase that is active and stable at low $\mathrm{pH}$ from the Bacillus sp. KR-8104. Enzym Microb Technol 36:666-671

Sambrook J, Russell D (2001) Molecular cloning: a laboratory manual, 3rd edn. Cold Spring Harbor Laboratory Press. ISBN 978-0-87969$577-4$

Santiago-Gómez MP, Vergely C, Policar C, Nicaud JM, Belin JM, Rochette L, Husson F (2007) Characterization of purified green bell pepper hydroperoxide lyase expressed by Yarrowia lipolytica: radicals detection during catalysis. Enzym Microb Technol 41:13-18

Sarikaya E, Higasa T, Adachi M, Mikami B (2000) Comparison of degradation abilities of $\alpha$ - and $\beta$-amylases on raw starch granules. Process Biochem 35:711-715

Sivaramakrishnan S, Gangadharan D, Nampoothiri KM, Soccol CR, Pandey A (2006) $\alpha$-Amylases from microbial sources - an overview on recent developments. Food Technol Biotechnol 44:173184

Sun H, Zhao P, Ge X, Xia Y, Hao Z, Liu J, Peng M (2010) Recent advances in microbial raw starch degrading enzymes. Appl Biochem Biotechnol 160:988-1003

Titarenko E, Chrispeels MJ (2000) cDNA cloning, biochemical characterization and inhibition by plant inhibitors of the alpha-amylases of the Western corn rootworm, Diabrotica virgifera. Insect Biochem Mol Biol 30(10):979-990

van der Maarel MJEC, van der Veen B, Uitdehaag JCM, Leemhuis H, Dijkhuizen L (2002) Properties and applications of starch-converting enzymes of the a-amylase family. J Biotechnol 94:137-155

Verbeke J, Beopoulos A, Nicaud JM (2013) Efficient homologous recombination with short length flanking fragments in Ku70 deficient Yarrowia lipolytica strains. Biotechnol Lett 35:571-576

Yang CH, Liu WH (2007) Cloning and characterization of a maltotrioseproducing alpha-amylase gene from Thermobifida fusca. J Ind Microbiol Biotechnol 34:325-330

Yang CH, Huang YC, Chen CY, Wen CY (2010a) Expression of Thermobifida fusca thermostable raw starch digesting alphaamylase in Pichia pastoris and its application in raw sago starch hydrolysis. J Ind Microbiol Biotechnol 37:401-406

Yang CH, Huang YC, Chen CY, Wen CY (2010b) Heterologous expression of Thermobifida fusca thermostable alpha-amylase in Yarrowia lipolytica and its application in boiling stable resistant sago starch preparation. J Ind Microbiol Biotechnol 37:953-960

Yuzbashev TV, Yuzbasheva EY, Vibornaya TV, Sobolevskaya TI, Laptev IA, Gavrikov AV, Sineoky SP (2012) Production of recombinant Rhizopus oryzae lipase by the yeast Yarrowia lipolytica results in increased enzymatic thermostability. Protein Expr Purif 82:83-89 